\begin{tabular}{|c|c|c|}
\hline \multicolumn{3}{|c|}{ PublisherInfo } \\
\hline PublisherName & : & Palgrave Macmillan UK \\
\hline PublisherLocation & $:$ & London \\
\hline PublisherImprintName & $:$ & Palgrave Macmillan \\
\hline
\end{tabular}

\title{
Using the FRS to examine employment trends of couples
}

\begin{tabular}{|l|l|l||}
\hline \multicolumn{2}{|c|}{ ArticleInfo } \\
\hline \hline ArticleDOI & $:$ & $10.1057 /$ palgrave.elmr.1410172 \\
\hline \hline ArticleCategory & $:$ & Feature \\
\hline \hline ArticleFirstPage & $:$ & 41 \\
\hline \hline ArticleLastPage & $:$ & 47 \\
\hline \hline & & RegistrationDate $:$ 2007-11-16 \\
ArticleHistory & $:$ & OnlineDate $\quad: 2007-11-16$ \\
\hline \hline ArticleCopyright & $:$ & Crown copyright2007 \\
\hline \hline
\end{tabular}


Antonia Simon, ${ }^{\text {Affl }}$

Elizabeth Whiting, ${ }^{\text {Aff1 }}$

\section{Presents findings on the demographic characteristics and employment trends of couples, both with and without dependent children.}

This article presents findings on the demographic characteristics and employment trends of couples. The Family Resources Survey (FRS) has been used to explore changes over time (between 1994/95 and 2005/06) for couples with and without dependent children, and differences in gross income and benefit receipt between work-rich couples (where both partners work), work-poor couples (where both partners are inactive or unemployed) and single-earner couples (where only one partner is employed). The FRS is used as it is the most detailed source of data on household income and benefit receipt. The article finds there has been a growth in the number of work-rich couples over time. However, the employment rate for partnered women with dependent children still lags behind those without children. Over time, gross real-term income has increased for all couples, but this increase has been greatest for work-rich couples.

The Full Text of this article can be found on the National Statistics website (http://www.statistics.gov.uk/elmr/11_07/downloads/elmr_nov07_simon.pdf). 